\title{
Sweet Grass In The Iron House
}

\section{Danny Homer}

A chronological history of Native spirituality is nothing more than an exercise in futility. Unlike Christianity which has well defined roots that can be traced, native spirituality has been in existence from time immemorial, or so legends say. This spirituality exists today and will continue to flourish as time goes by. What is new is the emergence of Native spirituality in federal and provincial prisons.

Because prison officials have not seen or heard of Native spirituality before, they feel threatened and in many cases attempt to suppress its practice. This is not at all foreign to the Indians. Modern history has shown time and time again that the government of Canada has not completely accepted Native people. In fact, it was not until the 1950s that Natives have had the right to practice their religion freely in open society.

The white man knows little about Native religion because Indians cherish unto themselves the gifts that the Creator has given to them. Many believe that their spiritual beliefs are just that ... theirs alone. For example:

our traditional teachings are ours and can never be shared with other races and nationalities. This is what was given to us by Sonkaitison, our Creator, for the

Onkwehonwe (North American Indian Travelling College, 1984: iv).

But just because the beliefs are not widely known is no reason for repression. All it comes down to is the Indian people are attempting to regain a strong hold on part of their culture.

A systematic shattering of Indian identity has occurred in the past. But, as prophesied through legend and stories, when the situation looked the bleakest the Indian people would come together. There are numerous methods used to accomplish the splitting of a people and the most effective continue to be used today.

Many Natives, after being separated from their people, end up in prisons with little or no knowledge of their culture. Thus, some elders have brought the culture to the prisons in an attempt to reclaim their people. It is interesting to note that their efforts have ignited debates among Natives. Some have argued that these prisoners have left the people (i.e., the reserves, bands, etc.) by choice, so why give them anything? It is also argued that spirituality cannot flourish in prison because jails are representative of evil forces; the trueness of the circle cannot be acquired because 
the prison is a square iron house. However, spirituality has emerged in the prisons because Natives are Natives, whether or not they are in jail.

Those who favour the efforts of these elders argue that since Natives have been taken away from their people (by the Children's Aid Societies, for example) and have not had opportunities to learn about their culture and heritage, they must be taught the traditional ways. And even more it has been argued that true Indians care for their brothers and sisters, so who is anyone to deny to them the knowledge of the Creator?

Native spirituality is a life-long, total commitment to the will of our Creator. Spirituality is not something that can be turned on or off. It keeps the individual in touch with the Native community and in touch with the Native tradition. It serves as a means of survival in the foreign environment of prisons; the prison experience is altered as a result of the commitment.

Indians have their own beliefs as to the origins of humanity, laws, and morals. The centre of Native beliefs revolves around honouring the Creator, his helpers (spirits) and that which was created. In its most simple form, nature is a beauty to behold. Natives have become one with nature; therefore, it is reasonable to assume that they know what they are doing when they use what nature has provided for their means of worship.

White people are not used to these worshipping rituals. Out of their ignorance and fear they have desecrated the sacred paraphernalia that is used in the ceremonies. Many prison officials (guards and administrative personnel alike) who do not know how to relate to these sacred objects show disrespect, contempt and ignorance about their use. This leads to one of the frustrations that Natives have to endure while incarcerated.

For example, sweetgrass, a grass that is used in the purification ceremony, is the most commonly known object used in prisons by Indians. Guards know it, have smelt the grass after it has been burnt, and yet in some prisons the sweetgrass is not allowed. Excuses have come up from nowhere to justify its ban. The most common one is that sweetgrass poses a fire hazard. Poor ventilation in the cells is another favorite excuse.

It is known from the beginning that hardships such as these will have to be endured. It is not without warning that the persecutions unfold before many Natives. Shock and bewilderment greet the Native once $s /$ he leaves the reserve for the first time. The white society has become so 'convenient' that almost anything can be bought. The pace of life is accelerated in the eyes of the first-time viewer. Rules of 
society, which may be taken for granted by many, are confusing and foreign to many Natives. An encroachment and breach of these rules will land many Natives in a yet stranger society, prison.

Although a report of the Standing Committee on Justice noted that '[s]ince the early 1980s, the rate of growth in the native proportion of inmates in federal institutions has exceeded the rate of growth of the inmate population as a whole' (Government of Canada, 1988: 211). Two of the most avoided and unanswered questions are: why are so many Natives in jails and prisons, and why are the numbers increasing at this rate.

But even while s/he endures such ridicule, the spiritually-aware Native person has supports to rely upon. The Creator has provided leaning posts to make the spiritual path a little easier to walk. Because the prison climate is such that its internal functions divide along cultural lines, Native brotherhoods and sisterhoods have formed, and these groups help to lessen the blow of the prison experience.

In Canadian prisons, social functions include brotherhoods and sisterhoods, although not all prisons recognize these groups as valid and permit them to exist. When they are permitted, they exist only as a means of socialization; not the progressive and innovative class that can be achieved through good leadership. Prison officials are content to sit back and have them function as a whitewash in the bureaucratic system. However, for the offender the groups allow an 'easing' of the frustration of doing time.

For the most part these groups create unity among their members. Personal burdens and responsibilities become shared experience. This unity allows the newly incarcerated Native a sense of belonging and identity. How far one gets into the spiritual aspects of the brotherhoods and sisterhoods depends on one's own judgment. Counsellors and elders and available for those needing assistance.

Brotherhoods and sisterhoods also have their drawbacks and failures. In general, the groups have what can be considered reliable volunteers; however, the occasional member has succumbed to the pressures of the prison administration and left once-honorable intentions in the dust. As in other segments of society, deceitfulness and selfishness exists everywhere. A few 'stings' and the groups become wary of whom they accept as counsellors. In the majority of cases, the prisoners are able to weed out those that do not belong, and the prisoners can rely on the brotherhood or sisterhood members for spiritual and emotional development. These groups have genuine interests in honour and its meaning, and shine as examples of the planting of the seeds of truth. 
The struggle to have what may appear to be considerable spiritual support has not been an easy one. Resistance by the authorities has been relentless. It has been partially penetrated by the persistence and diligence of Native spokespersons, elders and ex-offenders. Were it not for individuals like these, the foundation of spiritual awareness would be dealt a severe blow.

As a person grows spiritually, one's perspective of the world takes on a different meaning. The individual comes to understand what is happening around her/him and is able to adapt to and change the environment. S/he is also able to change the environment by her/his experience which in turn is able to change the prison experience. S/he can deal with the persecution of the authorities with an understanding of why the oppression is taking place. S/he knows strength from what is set before her/him and at times can feel the strength which was also experienced by the forefathers. The individual thus grows in maturity and is able to take on responsibilities customary for any mature person. The prison experience then becomes the fate of the prisoner herself/himself, for just as responsibility is accepted for spiritual growth, so will the opportunity be gained to choose one's own path.

\section{REFERENCES}

Government of Canada (1988) Taking Responsibility: Report of the Standing Committee on Justice. Ottawa: Supply and Services.

North American Indian Travelling College (1984) Traditional Teaching. Cornwall Island: By author. 